\title{
Water electrolysis based on renewable energy for hydrogen production
}

\author{
Jun Chi a,b, Hongmei Yu a,* \\ a Laboratory of Fuel Cells, Dalian Institute of Chemical Physics, Chinese Academy of Sciences, Dalian 116023, Liaoning, China \\ b University of Chinese Academy of Sciences, Beijing 100049, China
}

\section{A R T I C L E I N F O}

\section{Article history:}

Received 7 October 2017

Accepted 26 October 2017

Published 5 March 2018

\section{Keywords:}

Water electrolysis

Hydrogen production

Renewable energy

Abandoned solar power

Abandoned wind power

\begin{abstract}
A B S T R A C T
As an energy storage medium, hydrogen has drawn the attention of research institutions and industry over the past decade, motivated in part by developments in renewable energy, which have led to unused surplus wind and photovoltaic power. Hydrogen production from water electrolysis is a good option to make full use of the surplus renewable energy. Among various technologies for producing hydrogen, water electrolysis using electricity from renewable power sources shows great promise. To investigate the prospects of water electrolysis for hydrogen production, this review compares different water electrolysis processes, i.e., alkaline water electrolysis, proton exchange membrane water electrolysis, solid oxide water electrolysis, and alkaline anion exchange membrane water electrolysis. The ion transfer mechanisms, operating characteristics, energy consumption, and industrial products of different water electrolysis apparatus are introduced in this review. Prospects for new water electrolysis technologies are discussed.
\end{abstract}

(C) 2018, Dalian Institute of Chemical Physics, Chinese Academy of Sciences. Published by Elsevier B.V. All rights reserved.

\section{Introduction}

As global warming and related environmental issues become more serious the development of renewable energy sources has become more important. Renewable energy sources, such as wind and solar power, have transient characteristics, which require proper energy management and storage. From data reported by the National Energy Administration, the surplus unused wind power in China accounted for $497 \times 10^{8} \mathrm{kWh}$ in 2016 , and unused solar power in the northwest totaled more than $7 \times 10^{6} \mathrm{kWh}$; the total photovoltaic (PV) power output was 28.7 billion kWh, which means that approximately $20 \%$ of photovoltaic power was unused [1]. The installed photovoltaic capacity in the northwest area of China, i.e., Xinjiang, Gansu, Qinghai and Ningsia, is greater than $5000000 \mathrm{~kW}$. The distributed photovoltaic capacity in the middle east of China (i.e., Jiangsu, Zhejiang, Shandong, and Anhui) is greater than $1 \times 10^{6} \mathrm{~kW}$. In some areas (i.e., Xinjiang and Gansu) the unused photovoltaic energy respectively accounts for $32.23 \%$ and $30.45 \%$ of the total energy produced, as reported by the National Energy Administration [2]. Hydrogen is a more suitable energy storage medium than other fuels, owing to the high heat value of hydrogen. The energy density of hydrogen is $140 \mathrm{MJ} / \mathrm{kg}$, which is more than twice as high as that of typical solid fuels $(50 \mathrm{MJ} / \mathrm{kg}$ ). Hydrogen burns to produce water, making hydrogen an environmental friendly energy store. In terms of hydrogen storage, gaseous and liquid hydrogen can be stored in pressurized tanks, or in the solid state as

\footnotetext{
*Corresponding author. Tel: +86-411-84379051; Fax: +86-411-84379803; E-mail: hmyu@dicp.ac.cn

This work was supported by the Joint Fund of National Natural Science Foundation of China (U1664259), the National Natural Science Foundation of China (91434106), the State Grid Fund (SGTYHT/15-JS-193) and the Beijing municipal science and technology commission project (Z171100002017024).

DOI: 10.1016/S1872-2067(17)62949-8 | http://www.sciencedirect.com/science/journal/18722067 | Chin. J. Catal., Vol. 39, No. 3, March 2018
} 
metal hydrides. Therefore, the advantages of hydrogen as an energy carrier are not only its high energy density, but also that hydrogen and electricity can be interconverted through water electrolysis. Furthermore, hydrogen could be used in a grid when hydrogen production is scaled-up.

There are several technologies available for hydrogen production, including reforming, decomposition, and hydrolysis of fossil fuels. Approximately four billion tons of hydrogen are required annually, with $95 \%$ of hydrogen production derived from fossil fuel, which also produces $\mathrm{CO}_{2}$. Water electrolysis powered by renewable energy sources, is expected to enable the scale-up of hydrogen production, and zero $\mathrm{CO}_{2}$ emissions are produced in water electrolysis processes. Typical characteristics of main electrolysis technologies are listed in Table 1. Hence, storing surplus solar and wind energy as hydrogen shows great promise. Hydrogen generated from water electrolysis has high purity (99.9\%), and can also be used as a reactant for many industrial processes.

\section{Water electrolysis for hydrogen production}

In the water electrolysis process, water is the reactant, which is dissociated to hydrogen and oxygen under the influence of direct current.

$$
\text { Anode: } \mathrm{H}_{2} \mathrm{O} \rightarrow 1 / 2 \mathrm{O}_{2}+2 \mathrm{H}^{+}+2 \mathrm{e}^{-}
$$

Cathode: $2 \mathrm{H}^{+}+2 \mathrm{e}^{-} \rightarrow \mathrm{H}_{2}$

Overall: $\mathrm{H}_{2} \mathrm{O} \rightarrow \mathrm{H}_{2}+1 / 2 \mathrm{O}_{2}$

Different electrolytes systems developed for water electrolysis include alkaline water electrolysis (AWE), proton exchange membranes (PEMs), alkaline anion exchange membranes (AEMs), and solid oxide water electrolysis (SOE). Different materials and operating conditions are used in these systems; however, the operating principles are the same. On the basis of different operating temperatures, low and high temperature water electrolysis are also possible.

\subsection{Alkaline water electrolyzer for hydrogen production}

Alkaline water electrolysis operates at low temperature $\left(60-80{ }^{\circ} \mathrm{C}\right)$, with $\mathrm{KOH}$ and/or $\mathrm{NaOH}$ aqueous solution as the electrolyte, the concentration of the electrolyte is approximately $20 \%-30 \%$. In an alkaline electrolyzer, the diaphragm is asbestos, and nickel materials are used as the electrode. The purity of the generated hydrogen is approximately 99\%; however, an alkali fog in the generated gas must be removed, for which desorption is typically used. The maximum operating current density of an alkaline electrolyzer is less than 400 $\mathrm{mA} / \mathrm{cm}^{2}$, and the power consumption for $\mathrm{H}_{2}$ production is approximately $4.5-5.5 \mathrm{kWh} / \mathrm{Nm}^{3}$ with an efficiency of approximately $60 \%$. To avoid hydrogen/oxygen penetrating the po-

Table 1

Typical characteristics of main electrolysis technologies. Reprinted with permission from Ref. [3], copyright 2017 Elsevier.

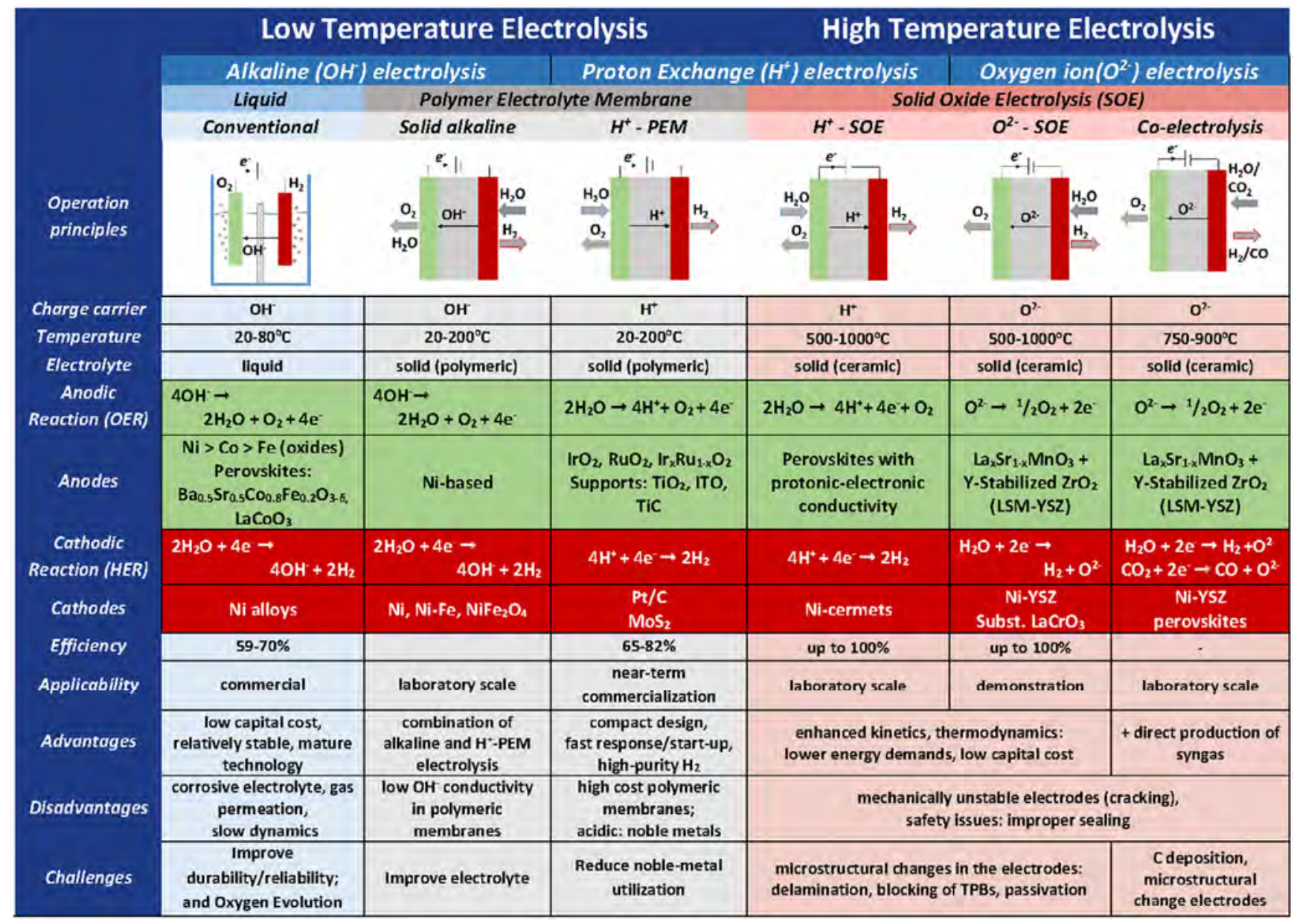


rous asbestos diaphragm resulting in an explosion risk, the pressure between the anode and cathode sides must be balanced. Moreover, alkaline electrolyzers cannot start up quickly, and have a slow loading response. Long start-up preparation makes it difficult to adapt alkaline electrolyzers to the variable nature of renewable energy sources [4]. Therefore, alkaline electrolyzers are normally used with a steady power input.

\subsection{Proton exchange membrane water electrolysis for hydrogen production}

PEM electrolysis is based on proton exchange membrane fuel cell technology. Proton exchange membranes replace asbestos, with protons conducted in the membrane. Notably the gas permeability of a PEM is much lower than that of asbestos. Without an alkaline fog in the generated gas, PEM electrolyzers are more environmental friendly. Furthermore, the fast response, high efficiency, compact design, and high output pressure make PEM electrolysis a promising hydrogen production technology. An early PEM commercial product was developed in 1978 [5]. The operating current density of this system (10 $\mathrm{A} / \mathrm{cm}^{2}$ ) was much higher than that of other alkaline water electrolysis technologies (Fig. 1). Additionally, balancing PEM electrolysis plants is much simpler, which is more attractive for industrial applications.

However, costs of the precious metals used as electrocatalysts for PEM electrolysis makes PEM electrolysis more expensive than alkaline electrolysis. Researchers have examined reducing the cost of PEM electrolysis, and improvements in the electrode materials have been made. The Department of Energy has targeted low-cost PEM electrolysis by 2020, see Table 2 .

PEM electrolysis has been evaluated as a suitable technology for converting wind power into hydrogen generation by the United States of America National Renewable Energy Laboratory [8], and the costs of scaling up a PEM electrolyzer have been predicted [9]. It is expected that the cost of a PEM electrolyzer will be reduced to $1 / 4$ of the current price when hydrogen generation reaches $1000 \mathrm{~kg} / \mathrm{d}$; current hydrogen generation systems are limited to $10 \mathrm{~kg} / \mathrm{d}$. Thus, large-scale PEM electrolysis for hydrogen generation should reduce costs.

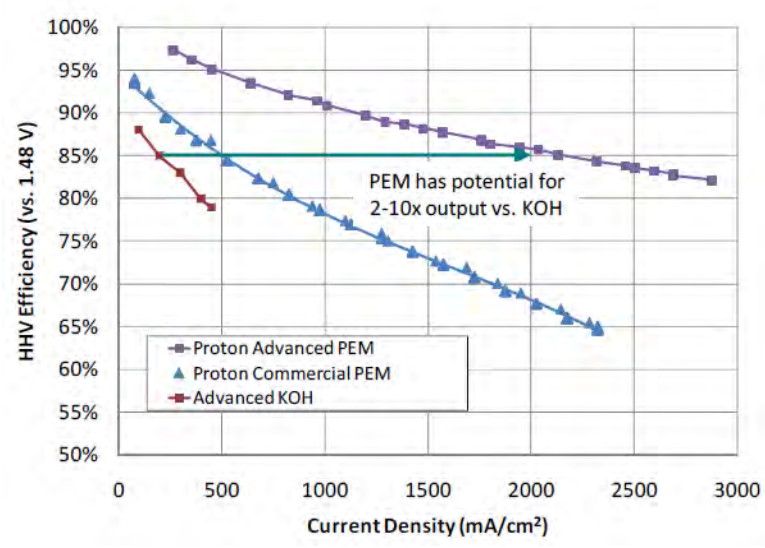

Fig. 1. Efficiency and operating current density of alkaline electrolysis and PEM electrolysis [6].
Table 2

Department of Energy targets for the cost of PEM water electrolysis [7].

\begin{tabular}{lccc}
\hline & & DOE 2015 target & DOE 2020 target \\
\hline Electrolyzer cost $\left(\$ / \mathrm{kg} \mathrm{H}_{2}\right)$ & 0.50 & 0.50 \\
$\mathrm{H}_{2}$ production cost $\left(\$ / \mathrm{kg} \mathrm{H}_{2}\right)$ & 3.90 & $<2.30$ \\
Electrolyzer efficiency & $\mathrm{LHV}(\%)$ & 76 & 77 \\
\multirow{3}{*}{ System efficiency } & $\mathrm{kWh} / \mathrm{kg}$ & 44 & 43 \\
& $\mathrm{LHV}(\%)$ & 72 & 75 \\
& $\mathrm{kWh} / \mathrm{kg}$ & 46 & 44 \\
\hline
\end{tabular}

Recently, a MW scale PEM electrolyzer was delivered by Proton Onsite and Siemens, reflecting that PEM electrolysis is on the way to industrial applications [10]. Shell, together with ITM Power, plans to install a $10 \mathrm{MW}$ electrolyzer to produce hydrogen at the Wesseling refinery site within the Rheinland Refinery Complex [11]. The advantages of rapid start-up and response make PEM electrolysis a promising technology for handling the intermittent supply of renewable energy.

Large-scale hydrogen production as an energy storage medium with the use of electricity from wind power could be feasible, if the difficulty of wind power in the grid could be resolved. In September 2016, a wind and solar powered hydrogen filling station, the Tongji-Sunrise filling station, was built at Dalian. At that time a $10 \mathrm{MW}$ electrolysis system with $\mathrm{H}_{2}$ capacity of $17520000 \mathrm{Nm}^{3} \mathrm{H}_{2} / \mathrm{y}$ was also announced in Hebei province [12].

Improving the effectiveness of electrocatalysts is a common strategy for improving the performance of water splitting. Catalytic activity is an important parameter in the evaluation of their performance. Long-term stability is another key parameter in assessing the quality of electrocatalysts for water splitting. Numerous studies on nanostructured electrocatalysts for water splitting in PEM water electrolysis have been published. $\mathrm{RuO}_{2}$ and $\mathrm{IrO}_{2}$ are ranked as the top catalysts for PEM water oxidation; while Pt is considered to be the benchmark electrocatalyst for the hydrogen evolution reaction (HER). However, the high cost of these precious metals prevents their large-scale practical application. Research on electrocatalysts for oxygen evolution reaction (OER) with high activation, good durability, and low cost is necessary to increase the energy efficiency and electrolyzer stability. Advances in this area could decrease the cost of $\mathrm{H}_{2}$ generation, and further accelerate the commercial development of the PEM water electrolysis technology. Considerable efforts have been made to synthesize iridium oxide-based electrocatalysts and study their performance. One method of reducing the electrode cost and improving the effectiveness is to introduce a second less-expensive metal, such as $\mathrm{Ru}, \mathrm{Sn}$, and Co. Another approach is to use a preparation method that gives good control over the electrode morphology at the nanoscale to enhance the electrocatalyst performance toward OER.

Thus, the use of less-expensive metals and electrode preparation methods that improve morphology at the nanoscale, could lead to considerable improvements in electrocatalyst performance toward OER [13]. Noble-metal Ir loading can be decreased to $0.78 \mathrm{mg} / \mathrm{cm}^{2}$ (a loading of $1.2 \mathrm{mg} / \mathrm{cm}^{2}$ is typical in 
previous reports). For example, with the use of an $\operatorname{Ir}_{x} \mathrm{Sn}_{1-x} \mathrm{O}_{2}$ anode catalyst (Ir loading ca. $0.78 \mathrm{mg} / \mathrm{cm}^{2}$ ) with a long blocklength, the cell voltage achieved was only $1.621 \mathrm{~V}$ at 1000 $\mathrm{mA} / \mathrm{cm}^{2}$ and $80{ }^{\circ} \mathrm{C}$, equating to a thermal energy efficiency of 91.3\%.

\subsection{New technologies for water electrolysis}

High temperature solid oxide electrolysis (SOEC) has high energy efficiency; when the heat utilization is included, the efficiency is more than $90 \%$. With the use of $\mathrm{ZrO}_{3}$ doped with 8-mol\% $\mathrm{Y}_{2} \mathrm{O}_{3}$ as the electrolyte, anions transfer at high temperature in the SOEC. The solid oxide is thermally and chemically stable. Water electrolysis at high temperature requires a lower voltage, which means lower energy consumption [14]. The thermal efficiency of high temperature water electrolysis can reach $100 \%$ [15]. However, high temperatures present challenges in terms of material degradation and the duration of SOEC operation can be an issue. The generated hydrogen mixture with water vapor from SOEC requires additional treatment to obtain high purity hydrogen. Thus, SOEC technology is currently still under development. Sunfire is now testing an SOEC prototype for a hydrogen filling station in Karlsruhe, Germany [16].

There is great interest in developing naturally abundant nanomaterials that show high activities for HER / OER reactions and high stability for practical applications [17]. Hence, research interest has shifted to investigations of naturally abundant metal resources, such as $\mathrm{Ni}, \mathrm{Fe}$, and Co-based materials for alkaline water electrolysis. For the oxygen evolution reaction, Gao et al. [18] reported that nanostructured $\alpha-\mathrm{Ni}(\mathrm{OH})_{2}$ spheres exhibited a small overpotential of $0.331 \mathrm{~V}$ at $10 \mathrm{~mA} / \mathrm{cm}^{2}$, and a small Tafel slope of $\sim 42 \mathrm{mV} / \mathrm{dec}$, characteristics that were comparable to those of $\mathrm{RuO}_{2}$ catalysts. In addition, $\alpha-\mathrm{Ni}(\mathrm{OH})_{2}$ spheres have exhibited improved durability over $\mathrm{RuO}_{2}$. A study conducted by Ma et al. [19] showed that a $\mathrm{Co}_{3} \mathrm{O}_{4} / \mathrm{C}$ porous nanowire array had the capacity to achieve a current density of $10 \mathrm{~mA} / \mathrm{cm}^{2}$ at an overpotential of $0.29 \mathrm{~V}$, which was lower than that of $\operatorname{IrO}_{2} / \mathrm{C}(0.31 \mathrm{~V})$ and other reported noble-metal catalysts.

Pt is considered the benchmark electrocatalyst for HER owing to its low overpotential and high kinetics. However, this metal resource is a limited and its high cost has hindered its large-scale application to electrochemical water splitting processes. A number of non-noble-metal materials, such as transition-metal chalcogenides, carbides, and complexes, as well as metal alloys, have recently been widely studied for use as catalysts, or catalyst supports for HER. For example, Karunadasa et al. [20] synthesized a well-defined Mo(IV)-disulfide complex, which showed potential as a low-cost alternative to platinum for electrocatalytic generation of hydrogen. An additional study performed by Liu et al. [21] demonstrated that carbon nanotubes decorated with cobalt phosphide (CoP) nanocrystals exhibited superior HER catalytic activity in acidic media.

In summary, if replacement of proton exchange membranes with anion exchange membrane is successful, both the advantages of alkaline water electrolysis and PEM water electrolysis can be realized. Thus, AWE water electrolysis can be applied more widely. Ni, Co, and Fe could act as electrocatalysts in AEM water electrolyzers, and the costs of AEM systems will be much lower than that of PEM water electrolyzers. The requirements for materials in AWE bipolar plates are also much easier to meet. Thus, AEMs show great promise as a water electrolysis technology, once the key material, i.e., alkaline membranes and electrocatalysts are developed.

\subsection{Prospects for water electrolysis based on renewable energy}

Today, China is the largest producer of hydrogen and over the past 7 years, hydrogen production in China has been ranked first worldwide. Owing to production economics, 95\% of that hydrogen production was derived from fossil energy. If the electricity usage of water electrolysis could be reduced, the hydrogen production industry would be considerably changed. The interconversion of electricity and hydrogen is becoming accepted by the public as a means of efficiently using abundant renewable energy.

Hydrogen from water electrolysis with high purity is applicable in the electronic, metallurgical, food, float glass, fine chemical, and aerospace industries. As an energy storage medium, in the future hydrogen could be used in hydrogen filling stations and HCNG, with a hydrogen production rate at $100-3000 \mathrm{Nm}^{3} / \mathrm{h}$. For these applications, bottled hydrogen and reformed hydrogen are not applicable. Water electrolysis technology generating hydrogen onsite from renewable energy without transportation could ensure efficient use. In the near

\section{Graphical Abstract}

Chin. J. Catal., 2018, 39: 390-394 doi: 10.1016/S1872-2067(17)62949-8

\section{Water electrolysis based on renewable energy for hydrogen production}

Jun Chi, Hongmei Yu*

Dalian Institute of Chemical Physics, Chinese Academy of Sciences;

University of Chinese Academy of Sciences

With the increment trend of abandoned wind power and PV power show increasing trend, water electrolysis is becoming promising. Different water electrolysis technologies have been discussed in this review.

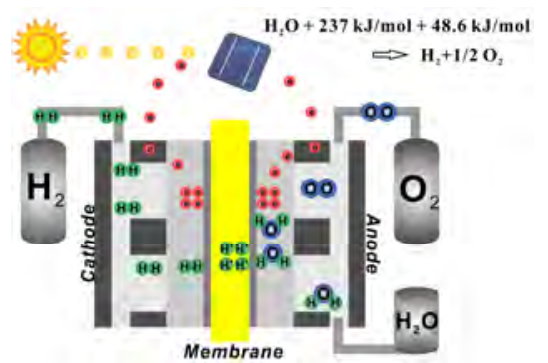


future, hydrogen as an energy storage medium will become more widely used.

\section{References}

[1] http://www.nea.gov.cn/2017-01/26/c_136014615.htm

[2] http://www.nea.gov.cn/2017-02/04/c_136030860.htm

[3] F. M. Sapountzi, J. M. Gracia, C. J. Weststrate, H. O. A. Fredresksson, J. W. Niemantsverdiet, Prog. Energy Combust. Sci., 2017, 58, 1-35.

[4] G. Gahleitner, Int. J. Hydrogen Energy, 2013, 38, 2039-2061

[5] A. Ursua, L. M. Gandia, P. Sanchis, Proc. IEEE, 2012, 100, 410-426.

[6] http://www.h2fc-fair.com/hm14/images/tech-forum-presentatio ns/2014-04-07-1630.pdf

[7] https://www.hydrogen.energy.gov/pdfs/review14/pd031_harris on_2014_o.pdf

[8] https://www.hydrogen.energy.gov/pdfs/review16/pd000_miller _2016_o.pdf

[9] Siemens: "Grüner" Wasserstoff. http://www.industry.siemens. com/topics/global/de/magazine/process-news/antriebstechnik/ seiten/pemelektrolyse.aspx (accessed 10.06.15)
[10] Proton Onsite: M1, M2. URL http://protononsite.com/products/ $\mathrm{m} /$ \#taboverview (accessed 10.06.15).

[11] http://www.greencarcongress.com/2017/09/20170901-shell.ht $\mathrm{ml}$

[12] www.china-hydrogen.org/fuelcell/mix/2016-12-06/5764.html

[13] G. F. Li, H. M. Yu, W. Song, X. Y. Wang, Y. K. Li, Z. G. Shao, B. L. Yi, J. Power Sources, 2014, 249, 175-184.

[14] M. A. Laguna-Bercero, J. Power Sources, 2012, 203, 4-16.

[15] A. Brisse, J. Schefold, M. Zahid, Int. J. Hydrogen Energy, 2008, 33, 5375-5382.

[16] http://www.sunfire.de/en/applications/hydrogen

[17] P. W. Du, R. Eisenberg, Energy Environ. Sci., 2012, 5, 6012-6021.

[18] M. R. Gao, W. C. Sheng, Z. B. Zhuang, Q. R. Fang, S. Gu, J. Jiang, Y. S.Yan, J. Am. Chem. Soc., 2014, 136, 7077-7084.

[19] T. Y. Ma, S. Dai, M. Jasonniec, S. Z. Qiao, J. Am. Chem. Soc., 2014, 136, 13925-13931.

[20] H. I. Karunadasa, E. Montalvo, Y. J. Sun, M. Majda, J. R. Long, C. J. Cheng, Science, 2012, 335, 698-702.

[21] Q. Liu, J. Q. Tian, W. Cui, P. Jiang, A. M. Asiri, X. P. Sun, Angew. Chem. Int. Ed., 2014, 53, 6710-6714.

\title{
基于可再生能源的水电解制氢技术
}

\author{
迟 军, ${ }^{\mathrm{a}, \mathrm{b}}$, 俞红梅, ${ }^{\mathrm{a}}$ * \\ a 中国科学院大连化学物理研究所燃料电池研究部, 辽宁大连 116023 \\ b 中国科学院大学, 北京 100049
}

摘要: 在全球变暖, 污染日益严重的今天, 发展可再生清洁能源成为了当务之急. 然而可再生能源(风能、太阳能)本身具有 间断特性, 这就需要寻找一种合适的能量媒介储存能量来保证其能源的稳定输出. 当前, 我国各地不断出现弃风、弃光和 弃水电事件, 据国家能源局的公开数据, 仅2016年, 全国弃风电量 $497 \times 10^{8} \mathrm{~kW} \cdot \mathrm{h}$, 弃光率仅西部地区就已达 $20 \%$, 弃风弃光 日臻凸显 [1]. 从地域方面来看, 我国光伏发电呈现东中西部共同发展格局, 其中, 西部地区主要发展集中式光伏发电, 新 疆、甘肃、青海、宁夏的累计装机容量均超过 $5 \times 10^{6} \mathrm{~kW} \cdot \mathrm{h}$, 而中东部地区除集中式光伏发电外, 还重点建设分布式光伏发 电, 江苏、浙江、山东、安徽的分布式光伏装机规模已超过100万千瓦. 我国光伏发电集中开发的西北地区也存在严重的 弃光问题. 根据中国光伏行业协会发布的报告, 我国的弃光现象主要集中于西北的新疆、甘肃、青海、宁夏和陕西五省区. 据统计, 2016年, 五省区光伏发电量 $287.17 \times 10^{8} \mathrm{~kW} \cdot \mathrm{h}$, 弃光电量 $70.42 \times 10^{8} \mathrm{~kW} \cdot \mathrm{h}$, 弃光率为 $19.81 \%$, 各省区光伏发电并网运 行数据如表格所示. 可以看出, 新疆、甘肃光伏发电运行较为困难, 弃光电量绝对值高, 弃光率分别达到 $32.23 \%$ 和 $30.45 \%$ [2]. 在新能源体系中, 氢能是一种理想的二次能源, 与其它能源相比, 氢热值高, 其能量密度 $(140 \mathrm{MJ} / \mathrm{kg})$ 是固体燃料(50 $\mathrm{MJ} / \mathrm{kg}$ )的两倍多. 且燃烧产物为水, 是最环保的能源, 既能以气、液相的形式存储在高压罐中, 也能以固相的形式储存在储 氢材料中, 如金属氢化物、配位氢化物、多孔材料等. 对可再生和可持续能源系统, 氢气是一种极好的能量存储介质. 氢气 作为能源载体的优势在于：(1)氢和电能之间通过电解水技术可实现高效相互转换; (2)压缩的氢气有很高的能量密度; (3) 氢气具有成比例放大到电网规模应用的潜力.

制氢的方式有很多, 包括: 化石燃料重整、分解、光解或水解等. 全球每年总共需要约 40 亿吨氢气, $95 \%$ 以上的氢气是 通过化石燃料重整来获得, 生产过程必然排出 $\mathrm{CO}_{2}$, 而电解水技术利用可再生能源获得的电能进行规模产氢, 可实现 $\mathrm{CO}_{2}$ 的 零排放, 可将具有强烈波动特性的风能、太阳能转换为氢能, 更利于储存与运输. 所存储的氢气可用于燃料电池发电, 或单 独用作燃料气体, 也可作为化工原料. 通过水电解方式获得的氢气纯度较高, 可达 $99.9 \%$ 以.

关键词: 水电解; 制氢; 可再生能源; 弃光; 弃风

收稿日期: 2017-10-07. 接受日期: 2017-10-26. 出版日期: 2018-03-05.

*通讯联系人. 电话: (0411)84379051; 传真: (0411)84379803; 电子信箱: hmyu@dicp.ac.cn

基金来源：国家自然科学基金联合基金(U1664259); 国家自然科学基金(91434106); 国家电网项目(新型SPE析氧催化剂测试技术 研究, SGTYHT/15-JS-193); 北京市科学技术委员会项目(Z171100002017024).

本文的全文电子版由Elsevier出版社在ScienceDirect上出版(http://www.sciencedirect.com/science/journal/18722067). 